\title{
中竜選鉱工場における銅浮選操業と 大型浮選機の開発について
}

\section{I 、銅浮選操業について}

\section{1 改善の目的}

中竜鉣山の人形鈗床，仙翁鉣床に銅がわずかながら存 在しており亜鉛精鉣中に混入して悪影響をあたえるた め, 銅精鉣として回収することは，その収益性に加えて 亜鉛精鉣の品質向上にも資することになるので回収をは じめた。

\section{2 改善の具体的内容}

銅精鉣としての回収はかなり以前より試みられていた が粗鉱中の銅品位が低いこと, 鉱量が少ないこと, 銅と 亜鉛の分離がむずかしく銅精鉱中に鉛, 亜鉛, 磁硫鉄鉱 などの混入が多くて品位があがらないことなどのため安 定操業ができず覀鉛精鉱中に混入して亜鉛精鉱品位低下
日本亜鉛鉱業侏 中竜鉱山選鉱課

の一因となっていた。

このような状態の中で人形鉣床の下部の探鉣が進んだ 結果，銅が極めて低品位ながらある程度まとまった粗鉱 が確保される見透しができたことから，銅精鉱の回収技 術の開発が急務となった。このため43年 9 月より研究を 開始した。種々試験研究の結果, 硫酸による低 $\mathrm{pH} に よ$ るものが最も優れた結果を示したので，44年 7 月より第 1 図の系統で操業を開始したが，鉛精鉱中に亜鉛の含有 が増加し鉛精鉱品位が低下したので，第 2 図の系統に変 更しさらに第 3 図の系統に変更し銅一鉛優先浮選法を採 用し現在に至っている。

\section{3 改善の効果}

最近の操業成績の推移は第 1 表の通りであり，収益向 上と亜鉊精鈗の品質向上に寄与している。

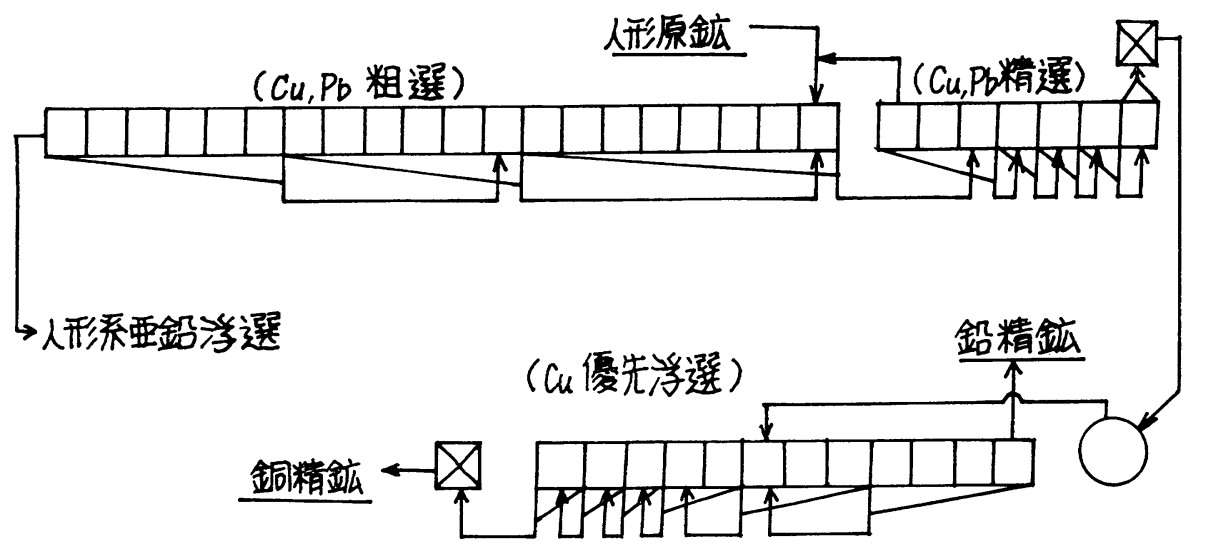

第1図 銅浮選操業開始時の系統

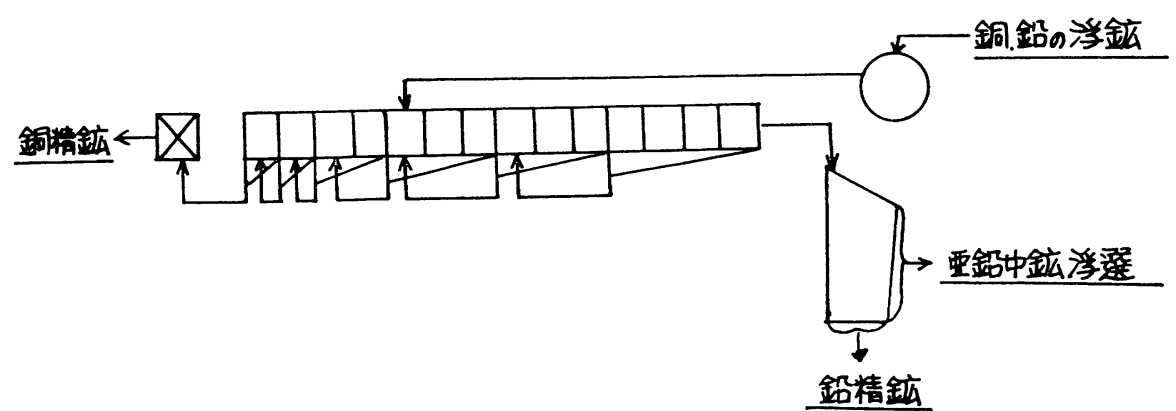

第 2 図鉛精鉱中に亜鉛の混入が多いため,テーブルを据付け，鉛と亜鉛の分離を行なう。 銅優先浮選尾鉱にテーブル据付け, および\# $18 \mathrm{FW} 2$ 槽増設 


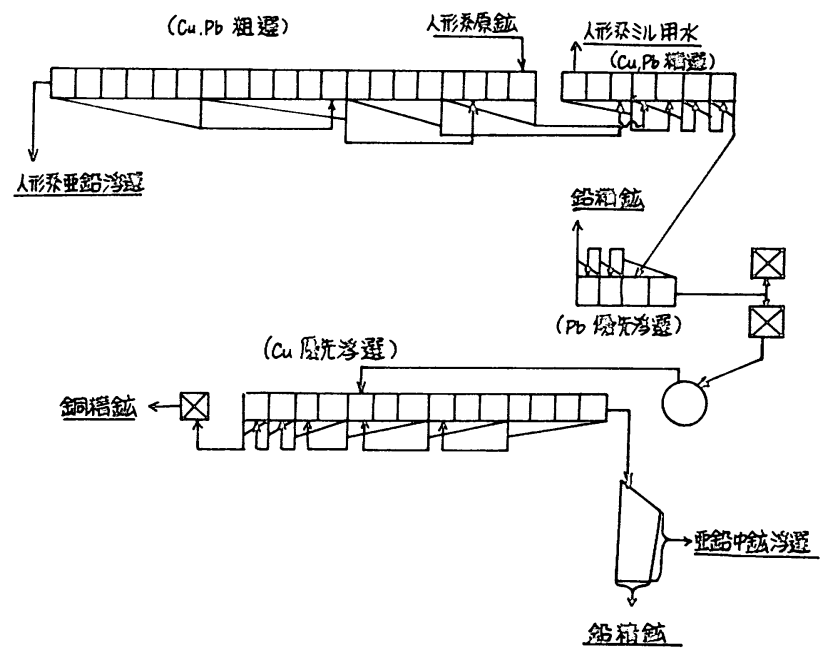

第 3 図 銅・鉛クリーナフロス中の $\mathrm{Pb}$ を採収するため\# $18 \mathrm{FW} 4$ 槽で鉛，銅の優先浮選を行なら。

第 1 表

\begin{tabular}{c|c|c|c|c}
\hline 期 別 & 精鉣量 & 粗鈗品位 & 精鉱品位 & 採収率 \\
\hline 上/45 & $139 \mathrm{t}$ & $0.15 \%$ & $29.42 \%$ & $19.9 \%$ \\
下/45 & 195 & 0.15 & 26.41 & 26.5 \\
上/46 & 214 & 0.14 & 26.96 & 31.0 \\
下 $/ 46$ & 240 & 0.16 & 26.83 & 31.2 \\
上/47 & 424 & 0.20 & 26.84 & 43.6 \\
下 $/ 47$ & 409 & 0.18 & 27.20 & 44.5 \\
\hline
\end{tabular}

\section{4 展望}

人形, 中山鈗混合処理時の銅浮選操業の可能性につい て追求を行なう。

\section{吕。大型浮選機の開発について}

\section{1 改善の目的}

当鉱山の $200 t$ /日増産設備增強工事が，昭和 45 年 7 月 に計画を行ない，46年 4 月より工事に着工した。計画の 中の亜鉛浮選設備についての基本的な考え方は

ア 現建家内に増設して建家の増築はしない

1 大型浮選機の採用を検討する

ウ 将来の増産計画に対応できる機種とする などを基本として検討を進めた。

\section{2 改善の基本的内容}

各種の浮選機について比較検討を行ったが，いずれの 機種を採用する場合でも機長が長くなり据付面積が大き くなり建家の増築が必要となり, 経費的な面や系統組立 上と将来の増産のことなどを勘案しても, この際大型浮 選機の開発が急務であると考えて, Vフロ一浮選機につ いていろいろの角度より検討を加えた結果, 大型化が可 能であるとの結論のもとに大塚鉄工株式会社と共同で大 型浮選機の製作試験を行なうことにした。
ア 浮選機の仕様比較

\section{1 比較試験結果}

現設の\#56ワーマン浮選機と\#80Vフロー浮選機との 比較試験を行った結果は次のとおりである。またVフロ 一浮選機は回転回流する機構であるため大型化してもサ ンドの沈積もなく機械的にも問題のないことが確認され た。

第 2 表

\begin{tabular}{|c|c|c|c|c|}
\hline \multicolumn{2}{|c|}{ 摘 } & 要 & \#56ワーマン浮選機 & \# $80 \mathrm{~V}$ フロー浮選機 \\
\hline \multicolumn{3}{|c|}{ セルの大きさ } & $\begin{aligned} 1,430 \times 1,430 \\
\times 510 \mathrm{~m} / \mathrm{m}\end{aligned}$ & $\begin{aligned} 2,000 \times & 2,000 \\
\times & 840 \mathrm{~m} / \mathrm{m}\end{aligned}$ \\
\hline 容 & & 積 & $1.04 \mathrm{~m}^{3}$ & $3.0 \mathrm{~m}^{3}$ \\
\hline 表 & 面 & 積 & $2.05 \mathrm{~m}^{2}$ & $3.6 \mathrm{~m}^{2}$ \\
\hline 電 & 動 & 機 & $5.5 \mathrm{~kW}$ & $11.0 \mathrm{~kW}$ \\
\hline
\end{tabular}

(1) \#80Vフロー浮選機は\#56ワーマン浮選機に対し て2.4倍の能力がある。

(2) \#80Vフロー浮選機は\#56ワーマン浮選機に対し て電力消費量は約 $15 \%$ 少ない。

（3）空気発生量は \#56ワーマン浮選機の 480～520l/ $\mathrm{m}^{2} / \mathrm{min}$ に対し \# $80 \mathrm{~V}$ フロー浮選機は $820 \sim 900 \mathrm{l} / \mathrm{m}^{2} /$ $\min$ と多い。

\section{3 改善の効果}

\# $80 \mathrm{~V}$ フロ一浮選機を開発採用したことにより基本構 想とおりに設備増強が終わり 47 年 5 月より順調に稼動し 所期の目的を果している。また本機を採用したことによ り経費も大巾に節減できたし所要槽数も約 $1 / 2$ となり操業 管理上も有利となり将来の増産計画にも対応できるよう になった。

\section{4 展 望}

Vフロー浮選機による粗粒浮選試験と \# 120 機の開発 試験を機会をみつけて実施したいと考えている。 